\title{
Organizing the new food labor movement: From neoliberal alternatives to worker- based justice
}

COMMENTARY ON RACE AND ETHNICITY IN FOOD SYSTEMS

\author{
Billy Hall* \\ Florida International University
}

Submitted June 16, 2015 / Published online August 14, 2015

Citation: Hall, B. (2015). Organizing the new food labor movement: From neoliberal alternatives

to worker-based justice. Journal of Agriculture, Food Systems, and Community Development, 5(4), 91-94.

http://dx.doi.org/10.5304/jafscd.2015.054.012

Copyright (C) 2015 by New Leaf Associates, Inc.

\begin{abstract}
Scholars and activists have launched numerous critiques against the alternative food movement, deriding its neoliberal politics and privileging of white notions and imaginaries of "good food." This commentary examines the recent formation of a U.S.-based food labor movement that is actively responding to the pitfalls of the alternative food movement and developing strategies for building coalitions across class, race, ethnicity, gender, and occupation. It also highlights some of the key ways the movement organizes around issues of discrimination, wage exploitation, and abuse throughout various sectors of the industrial food system, and challenges corporations to assume accountability in the ways workers are treated.
\end{abstract}

\footnotetext{
* Billy Hall, Department of Global \& Sociocultural Studies, Florida International University; $11200 \mathrm{SW} 8^{\text {th }}$ Street; Miami, Florida 33199 USA; +1-305-807-9908; whall002@,fiu.edu
}

\section{Keywords}

food labor, food movements, race, social justice

$\mathrm{T}$ he twenty-first century has seen an explosion of concern and activism around food. Much of this engagement has cohered, albeit loosely, around what many have called the "alternative food movement." Vocal largely around food issues related to pesticide and chemical use, carbon footprints, genetic modification, overprocessing, and factory farming, the alternative food movement has championed a politics of personal responsibility for effecting change in the food system, typically by promoting the buying and eating of local and organic food. Indeed, the alternative food movement's signature approach to responding to the environmentally destructive, industrial production of nutrient-deficient foods is fundamentally neoliberal, privileging individual "choices" of "voting with your dollar" and 
supporting alternative food producers and lifestyles (Guthman, 2008).

Of course, not everyone has access to and can afford to participate in this kind of movement. Many have derided the food movement for being too expensive and racially exclusive, highlighting the pervasive middle-class whiteness that occupies and colors the spaces and imaginaries of alternative food. Poor communities of color are often discursively portrayed as trapped and obese consumers in food deserts, uninformed shoppers who make poor decisions, or celebrity examples who help others "overcome" the plight of "unhealthy" diets through their popular food initiatives (e.g., Will Allen, First Lady Michelle Obama), while white, liberal consumers, gardeners, and nutrition educators are given privileged roles as movement leaders. Moreover, as some have noted, the movement has inherited a white farm imaginary, a set of values that orient the hard work in fields around an imagined white farmer, making invisible today's predominantly Latino farmworkers and marginalizing the historical struggles of black farmers and Latinoled groups like the United Farm Workers of America (Alkon \& McCullen, 2011; McCutcheon, 2013; Ramírez, 2015; Slocum, 2007). This argument can easily be extended to assert that the work of people of color throughout the food system has also been grossly overlooked and underappreciated.

In more recent years, however, a new food labor movement has begun to form across the U.S., bringing awareness to and addressing the unjust rules and practices within the food system that abuse and mistreat not just food but also the people who make it. Composed mainly of labor organizations, social justice groups, and food workers, this movement combats the many forms of exploitation that have become normalized in food labor: low wages or unpaid labor, unsafe or cruel working conditions, racial and gender discrimination, and sexual abuse. Groups like the Coalition of Immokalee Workers (CIW) and the Restaurant Opportunities Center United (ROC United) have filed litigation to redress cases of modern-day slavery and wage theft, respectively. These efforts confront the lax regulation around exploitation and the discriminatory policies and practices that disproportionally affect women, people of color, and immigrants - the three groups that form the backbone of food system labor. The food labor movement thus advocates for "good jobs" as well as "good food" (Myers \& Sbicca, 2015).

In addition, the food labor movement conscientiously aims to avoid many of the mistakes made by the alternative food movement by intentionally building an inclusionary coalition that confronts multiple axes of inequality, places workers in leadership roles, and represents a diversity of worker interests in the food system. Spaces are also created for food workers to communicate their grievances, understand them as part of a wider phenomenon, and strategize measures for enacting more just relationships with food corporations and employers.

For several years, as a researcher and food justice ally, I have had the opportunity to observe and take part in a slice of this movement from the geographic corner of South Florida, a node of growing importance in regional and global networks of radical food justice organizing. I have attended several local organizational meetings for strategizing lowwage worker campaigns and actively participated in public demonstrations led by the Service Employees International Union (SEIU), the Organization United for Respect at Walmart (OURWalmart), and the Coalition of Immokalee Workers (CIW). As a participant observer and scholar-activist in these settings, I have become more attuned to the ways in which workers, unions, and labor groups expose injustices within the corporate food system and advocate for policy changes.

For instance, the SEIU-led "Fight for $\$ 15$ " campaign mobilizes planned nationwide strikes, worker testimonies, and various forms of media to draw attention to the nation's widest pay gap between corporate chief executive officers (CEOs) and low-level fast food workers and to the effects of low-wage work on the quality of life of ordinary Americans. Demanding higher wages and the right to unionize for fast food workers, the "Fight for $\$ 15$ " campaign aims to secure significantly improved working conditions for workers in an industry that pays the minimum wage to the largest portion of its employees and is notoriously antiunion (Schlosser, 2001). The CIW also stages rallies, pressuring major growers and corporate 
buyers to enter into the Fair Food Program, a legally binding agreement that ensures that workers earn better wages, receive education about their rights, and have their protection standards regularly monitored and upheld. Contrary to the alternative food movement's neoliberal politics of consumer choice, both of these examples identify corporations as primary agents for enacting food system change. As corporations continue to distance and absolve themselves from any responsibility in the treatment and compensation of rank-and-file workers (while profiting from their exploitation), food labor campaigns aim to radically alter the terrain of corporate food business practice by reinscribing CEOs and corporate headquarters within an ethical relationship of accountability.

In May 2014 I was graciously welcomed to attend the Food Chain Workers Alliance (FCWA) annual retreat, which provided me with an inside look into the most intentional U.S.-based effort to link workers' struggles across the food system's many sectors. The FCWA officially formed in 2009 following a meeting between several organizations at the Labor Notes conference in 2008 in Dearborn, Michigan. As one FCWA leader explained at the retreat, "Michael Pollan was publishing book after book after book, and there was a lot of exciting conversation about food, but we were all saying, 'Who brings the food to the table?"' In just a few years the FCWA has successfully formed a broad coalition of worker-based organizations, including the CIW and ROC United, representing agricultural, processing, warehousing, retail, and restaurant and hospitality industries. Their work brings to light a number of worker-related issues that have historically been siloed and muted within their respective sectors, and builds a network that fosters communication, support, and strategizing across the food chain (Lo, 2014; Lo \& Jacobson, 2011). To bridge the geographic and perceived occupational distances, one FCWA leader stated, "We're not actually in different industries. The product is food, and we in this room are the ones making the food." During my two-day participation, I listened to dozens of workers and leaders share their stories of mistreatment and discrimination. Each story was unique yet resonated with the experiences of other workers facing similar conditions. The main message was perhaps most succinctly verbalized by a meatpacker from Arkansas: "We want to take the ingredient of abuse out of our food."

Throughout the retreat, nearly every word that was uttered was translated from English to Spanish or vice versa by a translator well familiar with social justice concepts and terminology. Participants also learned each other's protest chants, from "Qué queremos? Justicia! Cuándo? ¡Ahora!” ("What do we want? Justice! When do we want it? Now!") to "El pueblo, unido, jamás será vencido!" ("The people, united, will never be defeated!'). This speaks to the active steps taken by the FCWA and other groups to build a more inclusive movement. One segment of the retreat featured a workshop on issues related to class, immigration, race, gender, and LGBTQ identity. Participants were encouraged to list topics of concern on a whiteboard that then prompted discussion and the sharing of thoughts and experiences. The "Immigration" heading elicited the most fodder for understanding, as several members of the CIW and other predominantly Latino laboring industries described story after story about encounters with U.S. Immigration and Customs Enforcement (ICE) and immigration police, or "La Migra," human trafficking, and threats of deportation from farm crew leaders. A trained facilitator then skillfully situated these narratives within the history of policies that shape labor in agriculture and food processing.

In Miami, I have also seen a concerted effort among food labor activists to form relationships with prominent members of the clergy, some of whom have taken key leadership roles recently in the newly reinvigorated labor movement. I have witnessed the growing of a coalition predicated on becoming multilingual, intersectional, interfaith, and intercultural in a very real way. Far from espousing the vapid rhetoric of multiculturalism (and the cultural exoticism embraced by many "foodies"), the food labor movement incorporates a range of voices in its work toward dismantling the systemic forms of injustice that beset workers inhabiting various axes of difference.

Over 50 years ago the 1960 CBS documentary Harvest of Shame featured a quotation from a farmer that still exemplifies labor relations within the 
entirety of the corporate food system today: "We used to buy our slaves; now we just rent them." The quotation calls attention to the roots of the modern industrial food system, a system built atop a foundation of chattel slavery and racial subjugation. For major producers, profit has always depended on an available supply of cheap labor, and race and gender have been the primary determinants for ordering bodies in the fields, in the market, in the factory, and in the restaurant. Today's farmworkers and food workers are living a legacy of conditions that may not be identical to formal slavery but are nonetheless dehumanizing. These conditions are often hidden within remote agricultural landscapes or even inside our favorite dining spaces, "behind the kitchen door" (Jayaraman, 2013).

As the industrial food system continues to produce rising patterns of inequality, precarious low-wage work, hunger, corporate consolidation, and climatic threats to life-giving systems, there appears to be little way out but through collectives unified in the struggle to ensure that food is not only healthy and abundant but is made by people who can enjoy a dignified quality of life. In a recent interview, Eric Holt-Giménez, executive director of the Institute for Food and Development Policy, argued for a "triangulation for change... between the farm worker, the consumer and the food worker" (Al Jazeera America, 2015, para. 27). This would require a radical change beyond the neoliberal consumerist fetishization of food commodities towards an ethics of care and solidarity between people living and working in far-flung places and under sometimes vastly different contexts. Building an effective movement to address contemporary food issues will only be as successful as it is inclusive and beneficial for those most marginalized by the food system. As food activism moves forward in working to bridge the many real and discursive gaps that socio-spatially separate our communities, I am reminded of and humbled by a quotation from an Aboriginal activists group in Queensland, Australia: "If you have come here to help me, you are wasting your time. But if you have come because your liberation is bound up with mine, then let us work together" (Mz.Many Names, 2008, para. 1).

\section{References}

Al Jazeera America. (2015, June 18). Policy expert: Walmart has "immense power" over food system. Retrieved from http://america.aljazeera.com/ watch/shows/fault-lines/articles/2015/6/18/foodpolicy-expert-walmart-has-immense-power-overfood-system.html

Alkon, A. H., \& McCullen, C. G. (2011). Whiteness and farmers markets: Performances, perpetuations... contestations? Antipode, 43(4), 937-959. http://dx.doi.org/10.1111/j.1467-8330.2010. 00818.x

Guthman, J. (2008). Neoliberalism and the making of food politics in California. Geoforum, 39(3), 1171-1183. http://dx.doi.org/10.1016/i.geo forum.2006.09.002

Jayaraman, S. (2013). Bebind the kitchen door. Ithaca, New York: Cornell University Press.

Lo, J. (2014). Racism, gender discrimination, and food chain workers in the United States. In W. D. Schanbacher (Ed.), The global food system: Issues and solutions (pp. 59-82). Santa Barbara, California: ABC-CLIO.

Lo, J., \& Jacobson, A. (2011). Human rights from field to fork: Improving labor conditions for food-sector workers by organizing across boundaries. Race/ Ethnicity: Multidisciplinary Global Contexts, 5(1), 61-82. http://dx.doi.org/10.2979/racethmulglocon.5.1.61

McCutcheon, P. (2013). "Returning home to our rightful place": The Nation of Islam and Muhammad Farms. Geoforum, 49, 61-70. http://dx.doi.org/10.1016/i.geoforum.2013.05.001

Myers, J. S., \& Sbicca, J. (2015). Bridging good food and good jobs: From secession to confrontation within alternative food movement politics. Geoforum, 61, $17-26$. http://dx.doi.org/10.1016/j.geoforum.2015.02.003

Mz.Many Names. (2008, November 3). Attributing words [Blog post]. Retrieved from http://unnecessaryevils.blogspot.com/2008/11/ attributing-words.html

Ramírez, M. M. (2015). The elusive inclusive: Black food geographies and racialized food spaces. Antipode, 47(3), 748-769. http://dx.doi.org/10.1111/anti.12131

Schlosser, E. (2001). Fast food nation: The dark side of the all-American meal. New York: Houghton Mifflin.

Slocum, R. (2007). Whiteness, space and alternative food practice. Geoforum, 38(3), 520-533. http://dx.doi.org/10.1016/j.geoforum.2006.10.006 